\title{
Resmi İstatistiklere Göre Gümüşhane'de Milli Eğitim Hareketleri (1923-1960)
}

Öz

Osmanlı Devleti'nin son döneminde eğitimde bir takım modernleşme faaliyetleri başlatılmış olsa da, yeni Türk Devleti'ne eğitimde çözüm bekleyen birçok konu devredilmiştir. Cumhuriyet ilan edildikten sonra her alanda meydana gelen değişim eğitimi de etkilemiş, ülkenin her tarafında eğitimin modernleşmesi ve gelişimi adına hem şehirlerde hem de kırsal alanlarda bir dizi yenilik ve gelişmeler yaşanmıştır. Cumhuriyet Dönemi’nin eğitim politikaları, eğitimde laik ve milli bir yaklaşımla yeniden şekillendirilmiştir. Yeni devletin eğitimle ilgili ilk faaliyeti 3 Mart 1924 tarihli Tevhid-i Tedrisat Kanunu olmuştur. 1 Kasım 1928'de çıkarılan kanunla alfabe değişikliğine gidilerek eğitim seferberliği başlatılmış ve aynı yıl tüm yurt genelinde Millet Mektepleri açılmıştır. 1930'lu yıllarda faaliyete sokulan Halkevleri, halk dershaneleri ve kursları ile ülkenin eğitim ve kültür hayatına katkı sağlanmıştır. Kırsal kesime yönelik eğitimin yaygınlaştırılması ve öğretmen açığının kapatılması amacıyla da Köy Eğitmeni Projesi başlatılmışır. Tek parti döneminin zor şartları altında hayata geçirilen milli eğitim faaliyetleri DP iktidarına devredilmiştir. CHP ve DP dönemlerinin barındırdığı kendine has özellikleri içerisinde milli eğitim politikaları kısa ve uzun vadeli tedbirler eşliğinde ele alınmıştır.

Bu çalışmanın amacı; Gümüşhane'nin, incelenen dönem aralığında önemli bir eğitim merkezi olduğunu ortaya koymak, Gümüşhane'deki ilk, orta, lise ve teknik eğitim veren kurumların sayısal gelişimini, öğrenci- öğretmen durumlarını ve bu okulların Gümüşhane'nin eğitim hayatına katkısını incelemektir. Çalışmada metot olarak, veri toplama yöntemi olan dokümanincelemesi esas alınmış, MilliEğitim İstatistiklerive çeşitli telifeserler kullanılmıştır.

Anahtar Kelimeler: Eğitim, Gümüşhane, Okul, Öğrenci, Öğretmen.

\section{National Education Movements in Gümüşhane According to Official Statistics (1923-1960)}

\begin{abstract}
Although several modernization movements in education started in the last period of the Ottoman State, many problems that awaited solution were transferred to the new Turkish State. After the declaration of the Republic, the change that took place in every field also affected education, and a number of innovations and developments were made in both cities and rural areas on behalf of the modernization and development of education all over the country. The educational policies of the Republican Period were shaped again with a secular and national approach in educational field. The first activity of the new state in education was enacting the Unity of the Education Law on March 3, 1924. The alphabet was changed with a law that was enacted on November 1, 1928; and educational campaign was started, and in the same year, Nation Schools were opened all over the country. The Community Centers were opened in 1930s, and public courses were opened to contribute to the educational and cultural life of the country. For the purpose of spreading the education for rural areas and to cover the growing need for teachers, the Village Instructor Project was started. The National Education Activities that were started under the harsh conditions of Single-Party Period were transferred to the DP Government. National Education Policies were dealt with the short and long terms precautions in the specific conditions of the CHP and DP governments.

The purpose of this study was to reveal the importance of Gümüşhane as an educational center in the period in question. It was also aimed to examine the numerical development of the primary and secondary schools, high schools and technical schools, student-teacher status, and the contributions of these schools to the educational life of Gümüşhane. The Document Review Method, which is a data collection method, was used in the study. The statistics of the National Education and various copyright works were also made use of in the course of the study.
\end{abstract}

Keywords: Education, Gümüşhane, School, Student, Teacher.

\footnotetext{
* Bu çalışma, 16 - 18 Ekim 2017 tarihleri arasında düzenlenen 1.Uluslararası Gümüşhane Sempozyumu’nda sözlü bildiri olarak sunulmuştur.
} 


\section{Giriş}

Osmanlı Devleti'nin klasik dönemindeki eğitim anlayışı, gelenekçi bir İslam medeniyeti, Selçuklu dönemi ve daha eski dönemlerdeki bir üslupla şekillenmiş ve devletin eğitim politikası zaman içerisinde birtakım yeniliklere uğramıştır (Adıvar, 1991, s. 15). Önceki dönemlerde başlayan ve özellikle Tanzimat Dönemi ile devam eden yenileşme döneminde, Osmanlı eğitim politikası Batı'nın etkisiyle modern bir döneme girmiştir (Akyüz, 2011). Özellikle II. Abdülhamid (1876-1908) döneminde eğitim kurumlarında hızlı bir artış yaşanmış ve II. Meşrutiyet döneminde (1908-1914) de eğitim alanındaki gelişmeler devam etmiştir. I. Dünya Savaşı döneminin (1914-1918) olağanüstü şartları doğrultusunda eğitimdeki gelişmeler sınırlı olarak devam etmiş, Milli Mücadele'nin (1919-1922) en çetin döneminde Ankara'da, Maarif Kongresi toplanmıştır. Cumhuriyet’in ilan edildiği yıla mevcut eğitim kurumlarıla girilmiştir. Osmanlı Devleti'nin son döneminde eğitimde modernleşme faaliyetleri başlatılmış olsa da, yeni Türk Devleti'ne eğitimde çözüm bekleyen birçok konu devredilmiştir. Osmanlı'dan Cumhuriyet'e 364.428 öğrencinin eğitim gördüğü 5.142 adet eğitim kurumu intikal etmiştir (Milli Eğitim Bakanlığ1 [MEB], 2002). 1923 yılı sonunda yaklaşık olarak 11.900 öğretmen mevcuttur (Sakaoğlu, 2003, s. 167).

Osmanlı hâkimiyetinin ilk zamanlarında Erzurum eyaletine bağlı iken sonraları Trabzon'a bağlanan Gümüşhane sancağı 20 Nisan 1924 tarih ve 491 sayll kanunun 89. maddesinde "Vilayet" başlığ1 altındaki kanunla 1925 y1lında il olmuştur. 1925-1926 tarihli Trabzon salnamesinde "Gümüşhane Vilayeti merkez ilçe ile birlikte Bayburt, Kelkit, Torul ve Şiran olmak üzere 5 ilçe, 5 Bucak ve 377 köyden oluştuğu, 16.943 evde 101.153 kişinin yaşadığı belirtilmektedir. 1927'de yapılan Cumhuriyet döneminin ilk nüfus sayımına göre Gümüşhane vilayetinin toplam nüfusu 122.231'dir (Gümüşhane Belediyesi [GB], 2017).

\section{Erken Cumhuriyet Dönemi Gümüşhane'de Milli Eğitim Hareketleri}

Erken Cumhuriyet döneminde, laik bir eğitim anlayışı çerçevesinde, eğitimde milli bir anlayışla yeniden yapılandırma sürecine girildi. Bu süreçte yeni devletin eğitim, kültür ve ideolojisinin şekillenmesinde birçok eğitimci etkin rol oynadı. İlk önemli düzenleme 1924 Anayasası'nda ilköğretimin zorunlu ve devlet okullarının parasız olmasıydı (Akyüz, 1994). 3 Mart 1924 tarihinde 430 sayılı kanunla kabul edilen Tevhid-i Tedrisat Kanunu ile ülkedeki tüm eğitim kurumları Milli Eğitim Bakanlı̆̆ı'na (MEB'e) bağlandı. Ayrıca vakıflara bağlı tüm medrese ve mektepler MEB'in çatısı altında birleştirilerek bütçeleri de bu bakanlığa aktarıldı (Düstur, 1936). Aynı yıl gerçekleştirilen II. Heyet-i İlmiye Toplantısı'nda, yeni bir müfredat programıla birlikte ilkokul alt1 yıldan beş yıla indirildi ve haftalık ders saati 26'ya yükseltildi (Cicioğlu, 1985). 1926 tarihli ve 789 sayılı "Maarif Teşkilatına Dair Kanun" ile birlikte ilköğretim programı şehir ve köy biçiminde ikiye ayrıldı. Şehirlerde beş yıl, köylerde ise en az üç yıl eğitim yapan ilkokulların bulunması kararlaştırıldı. Beş yıllık ilkokullar, şehir-kasaba gündüz, şehir ve kasaba yatılı, köy gündüz ve köy yatılı okulları olarak yeniden düzenlendi (Kırpık, vd. 2012). Cumhuriyet döneminde eğitim hareketleri içerisinde en çok dikkat çeken gelişme, ilköğretimdeki gelişmelerdir (Hesapçıŏlu, 2013, s. 122). Bu doğrultuda erken Cumhuriyet döneminde Gümüşhane'deki eğitim politikaları şekillenmiştir.

1923-24 eğitim- öğretim yılında Gümüşhane'de 34 ilkokul, 39 öğretmen (34 erkek-5 kadın) ve 1.152 öğrenci (1.084 erkek-68 k1z) mevcuttu (Maarif Vekaleti, 1341). 1924-25 ders y1lında da 34 ilkokulda, 1.244 (1.147 erkek-98 kız) öğrenciye, 49 öğretmen (Duman, 2016) tarafindan eğitim verildi (Maarif Vekaleti, 1927). 1925-26 döneminde Gümüşhane genelindeki 55 ilkokulda 68 öğretmen, 1.513 öğrenciye (1.393 erkek-120 k1z) eğitim vermekteydi (Maarif Vekaleti, 1928). 1926-27 eğitim-öğretim yılında Gümüşhane'de ilkokul sayısı 67'e, öğretmen sayıs1 95'e (85 erkek-10 kadın) ve öğrenci sayıs1 da 2.128'e (1.985 erkek-143 kı) yükseldi. Ortaokulda ise 8 öğretmen, 29 öğrenciye eğitim vermekteydi. O yll ortaokul öğrencilerinden sadece 4'ü mezun olmuştu (Devlet İstatistik Enstitüsü [DİE], 1973). 
Görüldüğ̈̈ gibi Cumhuriyet'in ilanından 1928 harf inkılabına kadar olan süreçte Gümüşhane'deki eğitim faaliyetleri dönemin kısıtlı şartları altında belirli bir ivme kazanmıştır. Gerek okul, gerekse öğretmen ve öğrenci sayısında kısmen de olsa artış kaydedilmiştir. Bu durum ilkokulun zorunlu olmasından kaynaklanmıştır. Bununla birlikte 1926-27 ders yılında, okul, öğretmen ve öğrenci sayılarında önceki yıllara nazaran hızlı bir artışın yaşandığı gözlenmektedir. Bu artış, Bayburt kazasının Gümüşhane sınırları içerisine dâhil edilmesi ve buna bağlı olarak artan nüfus, okul, öğretmen ve öğrenci sayılarıyla yakından ilgilidir.

1 Kasım 1928'de çıkarılan 1353 sayılı kanunla (Düstur, 1936, s. 322) alfabe değişikliğine gidildi ve yeni alfabenin öğretilmesi için eğitim seferberliği başlatıldı. Bu amaçla tüm yurt genelinde "Millet Mektepleri”" açlldı. Millet mektepleri, 11 Kasım 1928 tarihli kararname ile kabul edilerek, 24 Kasım 1928 tarihinde yürürlüğe girdi (Resmî Gazete, 1928). Yeni Türk harflerini en kısa sürede öğretmek amacıyla 1 Ocak 1929'da açılan Millet mektepleri, A ve B kursları biçiminde örgütlendi. A kurslarına tahsil çağını geçirmiş, hiçbir şekilde okuma yazma bilmeyenler; B kurslarına ise eski yazıyı bilenler dâhil edildi. Bu doğrultuda Gümüşhane'de de Millet mektepleri eğitim alanında önemli bir boşluğu doldurdu. 1929-35 yılları arasında Gümüşhane'de faaliyet gösteren Millet mektepleri, 1935'den sonra Ulus okulları adıyla faaliyetlerine devam etti (Duman, 2016, s. 63). Bununla birlikte 1933'de açılan Gümüşhane Halkevi'nin, şehrin eğitim ve kültür hayatına sağladığ1 katkıyı da belirtmek gerekir. Halkevi ve halkodalarında, okuma- yazma bilmeyenlere yönelik yapilan çalışmalar oldukça önemlidir.

1934-35 ders yllına ait istatistik verilere bakıldığında, şehirde ilkokul binası ve öğretmen sayısında düşüş yaşandığı, öğrenci sayısında ise iki katı artış olduğu görülmektedir. İlkokul sayısının 49'a, öğretmen sayısının 86'ya (77 erkek-9 kadın) düştüğü şehirde, öğrenci sayısı 4.404'e (3.226 erkek1.178 kız) yükselmişti. Gümüşhane genelindeki ilkokullardan 93 erkek ve 23 kız olmak üzere toplam 116 öğrenci mezun olmuştu (DİE, 1973). Okul sayısındaki düşüşün sebebi olarak, çok eski olan okul binalarının kullanılamaz halde olması ve yerine yenilerinin yapılamaması gösterilebilir. Öğretmen sayısının düşüşü ise öğretmenlerin başka illere tayin edilmesi ya da çeşitli sebeplerden dolay1 görevlerinden ayrılmaları ile açıklanabilir.

Aynı dönemde ortaokul öğrencilerinin ve öğretmenlerinin sayısında ise ciddi bir artış olmuştu. Ortaokul sayısının 2'ye yükseldiği şehirde, 17 öğretmenle (16 erkek-1 kadın), 146 öğrenciye (137 erkek- 9 kız) eğitim verilmişti. Ortaokuldan mezun olanların sayısı ise 19 erkek ve 2 kız olmak üzere toplam 21 idi (DİE, 1973). Bununla birlikte eğitim alanındaki çabalara rağmen 1935'de, Gümüşhane'deki okuma-yazma bilenlerin oranının nüfusa göre oldukça düşük olduğunu belirtmek gerekir. En önemli husus ise okuma- yazma bilen kadın oranının bir hayli düşük seviyede olmasıdır. 1935'de Gümüşhane'de 6 ve daha yukarı yaşlardaki nüfus 162.667 kişi olup (78.301 erkek- 84.366 kadın), bu nüfusun ancak 12.383’ü (10.455 erkek- 1.928 kadın) okuma yazma bilmekteydi. Bu rakam 6 ve daha yukarı yaşlardaki nüfusun yalnızca \% 7.61'ine tekabül etmekteydi (DİE, 1973).

Şehirde faaliyet gösteren ve şehrin eğitim ve kültür hayatına katk1 sağlayan bir diğer kurum da halk dershaneleri ve kurslarıdır. 1934-35 öğretim y1lında şehirde, 12 halk dershanesi vardı. 12 öğretmenin görev yaptı̆̆ı bu dershanelerde, 241 kişi mezun olmuştu (DİE, 1973). En dikkat çekici husus ise bu kurslara, kadın öğretmen ve kursiyerlerin hiç katılmamış olmasıdır. Kadın öğretmenlerin olmaması, zayıf bir ihtimalle de olsa, kadın kursiyerlerin katılmamasına sebep olmuştur. Bu duruma daha çok şehrin sosyo-kültürel özelliğinin etkili olduğu söylenebilir.

1936’da kırsal kesime yönelik eğitimin yaygınlaştırılması ve öğretmen açı̆̆ının kapatılması amacıyla "Köy Eğitmeni Projesi” başlatıldı. TBMM’den çıkarılan 11 Haziran 1937 tarihli, 3238 sayılı ve 7 Temmuz 1939 tarihli, 3704 sayılı kanunlarla; askerliğini onbaşı veya çavuş olarak yapan gençler yetiştirilerek köylere gönderildi. Bu uygulama daha sonra kurulan Köy Enstitüleri'nin temelini oluşturdu (Akyüz, 1994). Köy Eğitmenleri Kanunu'nun yürürlüğe girmesiyle birlikte Gümüşhane'de de kanunun uygulanmasına başlandı. Bu dönemde şehirdeki öğretmen açığı, Köy Eğitmenleri ile kapatılmaya çalışıldı. 
1937-38 ders y1lında Gümüşhane'deki ilkokul sayısının 83’e yükseldiği, 136 öğretmenin, 6.696 öğrenciye eğitim verdiği görülmektedir. İlkokul öğretmenlerinin 32'si erkek ve 8'i kadın olmak üzere 40'ı resmi ilkokul öğretmeni, 32'si köy eğitmeni, geri kalanı ise 2 sınıflı, 3 sınıflı, 4 sınıflı, 5 sınıflı ve 6 sınıflı öğretmen okulu mezunu statüsündeydi. 2 ortaokulda ise 14 öğretmen ve 287 öğrencisiyle eğitim-öğretime devam etmekteydi (Başvekâlet İstatistik Umum Müdürlüğü [BİUM], 1942). Gümüşhane'de eğitimin artırılmasına yönelik çabaların devam ettiği bir dönemde 1939'da, II. Dünya Savaşı patlak verdi.

\section{9-1950 Yılları Arası Gümüşhane’de Milli Eğitim Hareketleri}

Gümüşhane'nin eğitim ve kültür hayatı; dönemin şartları gereği kısıtlı imkânlarla yürütülmeye çalışılmıştır. Özellikle eğitimdeki olumsuzlukları bertaraf etmeye yönelik yeni arayışlar içerisinde Gümüşhane'deki eğitim hayatında belirli bir ivme yakalanmıştır. Ancak eğitime yönelik yeni ihtiyaçların belirdiği ve bu anlamda kısmen de olsa olumlu gelişmelerin yaşandığı bir dönemde, 1939’da II. Dünya Savaşı başlamıştır. Dolayısıyla 1939-50 döneminin özelikle ilk yarısı, savaşın olağanüstü koşulları nedeniyle ülkemizin sıkıntıya düştügü bunalımlı bir zamanı kapsar. Ülke genelinde uygulamaya konulan zorunlu savaş ekonomisi, eğitim faaliyetlerini de yakından etkilemiş ve eğitim alanında daha fazla olması gereken yatırımları yavaşlatmıştır. Buna rağmen halkın eğitim ihtiyacını karşılamak ve öğretmen eğitimiyle ilgili sorunları çözüme kavuşturmak için önlemler alınmaya devam edilmiştir.

Bu dönemin öne çıkan en önemli faaliyetlerinden biri 1939'da Birinci Millî Eğitim Şûrası'nın toplanmas1, diğeri de 17 Nisan 1940 tarihli ve 3803 sayılı Köy Enstitüleri Kanunu idi. Birinci Millî Eğitim Şûrası'nda, üç sınıflı ve tek öğretmenli köy ilkokullarının beş sınıflı olmasına karar verildi. Köy Enstitüleri Kanunu’yla da köylünün eğitilmesi konusunun kökten çözülmesi amaçlandi. Diğer yandan 16 Haziran 1942 tarihli ve 4274 sayılı Köy Okulları ve Enstitüleri Teşkilat Kanunu ile uygulamanın kapsamı genişletildi (Cicioğlu, 1985).

1939-40 ders yllı içerisinde savaş öncesi yapımına başlanan okul binalarının faaliyete geçmesiyle birlikte şehir genelindeki ilkokul sayısının 132'ye yükseldiği görülmektedir. Bu okullarda 186 öğretmenle (174 erkek-12 kadın), 8.258 öğrenciye (5.987 erkek-2.271 kız) eğitim verildi. Okullardan 295 öğrenci (248 erkek-47 kız) mezun oldu. 2 ortaokulda ise 18 öğretmen (14 erkek-4 kadın), 402 öğrenciye (358 erkek-44 kı) eğitim vermekteydi. Ortaokullardan mezun olan öğrenci sayısı ise 68'i erkek, 7'si kız olmak üzere toplam 75'di (DİE, 1973).

1940’l1 ylllarda eğitim meselelerinin Cumhuriyet Halk Partisi’nin (CHP) il ya da ilçe kongrelerinde de tartışıldığı anlaşılmaktadır. Eğitim meselelerinin, yerel yetkililerin yanı sıra Ankara'daki üst düzey yetkililer tarafından da takip edildiği bilinmektedir. Bu dönemde devletin, memleketin her yerinde okul yaptırmak ve okuma yazma oranını artırmak için seferber olduğu ve bizzat dönemin Cumhurbaşkanı İsmet İnönü tarafindan, bu hususun yakından takip edildiği anlaşılmaktadır (Yavuz, 2016, s. 83). Bununla birlikte 1946’da Üçüncü Millî Eğitim Şûrası yapıldı ve nitelikli öğretmen yetiştirme konusu üzerinde duruldu. 1949'da toplanan Dördüncü Millî Eğitim Şûrası'nda da öğretmenlerin genel kültür ve meslekî formasyon bakımından daha iyi yetişmeleri gereğine değinildi ve bu amaçla eğitim enstitüleri ile Yüksek Öğretmen Okulu'nun yeniden düzenlenmesi yönünde kararlar alındı. (Milli Eğitim Bakanlığı [MEB], 2017).

Alınan tedbirler sayesinde 1944-45 eğitim-öğretim yllında, Gümüşhane'deki eğitim faaliyetlerinde her anlamda ciddi bir artışın yaşandığı anlaşılmaktadır. Bu dönemde şehirdeki ilkokul sayıs1 176'a, öğretmen sayısı 229'a (207 erkek-22 kadın), öğrenci sayısı ise 11.208'e (8.020 erkek-3.188 kız) yükseldi. İlkokullardan mezun olan öğrenci sayısı 513 erkek ve 93 kız olmak üzere toplam 606 idi. 2 ortaokulda ise toplam 19 öğretmen (14 erkek-5 kadın) ve 469 öğrenci (397 erkek-72 kız) mevcudu vardı. Ortaokullardan mezun olan öğrenci sayısı ise 106 (80 erkek-26 kı) idi. Bununla birlikte şehirdeki halk dershanelerinin sayısı 291'e yükseldi. Halk dershanelerinde 4'ü kadın olmak üzere 180 öğretmen görev yaptı. Eğitimler sonucunda halk dershanelerini, 2.479 erkek ve 1.375 kadın 
olmak üzere toplam 3.854 kişi bitirmişti. 1945'de Gümüşhane'de 6 ve daha yukarı yaşlardaki nüfus 147.752 kişi olup (69.563 erkek-78.189 kadın), bu nüfusun ancak 29.717'si (22.784 erkek- 6.933 kadın) okuma-yazma bilmekteydi. Bu rakam 6 ve daha yukar1 yaşlardaki nüfusun \% 20.11'ine tekabül etmekteydi. Kadın nüfus, erkek nüfustan fazla olmasına rağmen, kadın nüfusun okuma-yazma oranı yalnızca \% 8.87 idi (DİE, 1973).

1946-1950 yılları arasında ülke genelinde yapılan kamu harcamalarında birinci derecede önem verilen alan milli eğitim olmuştu.1946 yılı bütçe harcamalarında en yüksek pay MEB'e ayrılmış ve bu oran \% 11.74 şeklinde gerçekleşmişti. 1946-1950 yılları arasında ise MEB'e ayrılan payın ortalama oranı \% ise 12.08'di. Bu öncelik siyasi otoritenin tercihinden kaynaklanmaktaydı (Aşgın, 2000).

1949-50 ders y1lı ise gerek okul, gerekse öğretmen ve öğrenci sayısında en yüksek rakamlara ulaşıldığı dönemdi. İlkokul sayısının 219'a yükseldiği şehirde 388 öğretmen (320 erkek-68 kadın), 16.917 öğrenci (10.770 erkek-6.147 kı) mevcudu vardı. Bu okullardan 1.185 öğrenci (923 erkek-262 kız) diploma almaya hak kazanmıştı. Bu dönemde ortaokul sayısının 3'e yükseldiği, öğretmen sayısının kısmen arttı̆̆ı, buna rağmen öğrenci sayısının azaldığ1 görülmektedir. Buna göre 3 ortaokulun, 23 öğretmeni (17 erkek-6 kadın) ve 356 öğrencisi (304 erkek-52 kı) vardı. Mezun olan öğrenci sayısı ise 73 (63 erkek-10 kı) idi. Şehirdeki 2 mesleki ve teknik okulda 13 öğretmen, 111 öğrenciye eğitim verdi. Kız öğrencisinin olmadığı okullarda 23 öğrenci mezun oldu. Ayrıca şehirdeki tek akşam kız sanat okulu da, 2 öğretmen ve 65 öğrencisiyle faaliyetteydi. 1950'de 6 ve daha yukarı yaşlardaki nüfusun sayıs1 171.743 kişi (81.795 erkek- 89.948 kadın) olarak tespit edilmiştir. Nüfusun 38.929'u (29.021 erkek-9.908 kadın) okuma-yazma bilmekteydi. Okuma-yazma bilenlerin oranı ise \% 22.67 idi (DİE, 1973).

1939-1950 yılları arası Gümüşhane'deki eğitim politikalarının ana ekseni II. Dünya Savaşı'nın olumsuz etkisi altında şekillenmiştir. Ancak imkânsızlıklara rağmen bu dönemde CHP iktidarı, Gümüşhane'de eğitime yönelik faaliyetlerini artırarak devam ettirmiştir. CHP hükümetlerinin önceliği; okuma-yazma oranının yükseltilmesi, ilkokul binası ile nitelikli öğretmen sayısının artırılması olmuştur. $\mathrm{Bu}$ doğrultuda işbaşındaki hükümetler bu öncelikleri gerçekleştirebilmek için kısa ve uzun vadede tedbir almak suretiyle ciddi bir mesafe kat etmişlerdir. Bunun dışında açılan halk dershaneleri ile şehirdeki okuma-yazma oranı artırılmaya çalışılmıştır. Ayrıca bu dönemde faaliyete sokulan ortaokullar, mesleki ve teknik okullar ve akşam kız sanat okuluyla Gümüşhane'deki eğitim hayatı canlandırılmıştır. Dönemin zor şartları altında, CHP iktidarı döneminde Gümüşhane'de gerçekleştirilen eğitim faaliyetleri Demokrat Parti (DP) iktidarına devredilmiştir.

\section{0-1960 Yılları Arası Gümüşhane'de Milli Eğitim Hareketleri}

DP iktidarının başladığı 1950'de, devletin genel bütçesi 1 milyar 487 milyon liraydı. Bütçeden eğitime ayrılan pay ise 176 milyon lira civarındaydı. Genel bütçe içindeki MEB harcamalarının oranı \%11,8'di. DP iktidarının son yılında 1960'da ise genel bütçe 7 milyar 281 milyon lira olup, eğitime ayrılan pay 920 milyon lira civarındaydı. MEB'in genel bütçe içindeki harcamalarının oranı \%12,6'ydı (DİE, 1952; DİE 1964). Rakamlara bakıldığında DP'nin bir önceki iktidara göre oldukça avantajlı olduğu söylenebilir. DP iktidarını avantajlı hale getiren diğer bir husus II. Dünya Savaşı'nın sebep olduğu buhranlı yılların atlatılmasıdır. Bu durum, DP iktidarının elini güçlendirmiş ve bu dönemde eğitime ayrılan payın artırılmasını sağlamıştır. DP iktidarı Gümüşhane'de, CHP iktidarı döneminden kalan önemli ölçüde bir eğitim mirası devralmıştır. 1950'ye kadar Gümüşhane'deki eğitim faaliyetleri büyük ölçüde tamamlanmış ve DP dönemi eğitim faaliyetlerinin alt yapısını oluşturmuştur. 1950-1960 yılları arasında mevcut eğitim kurumlarının yanı sıra ihtiyaç dâhilinde yeni eğitim kurumları hizmete sokulmuştur.

DP iktidarında Gümüşhane'deki ilk eğitim verilerine 1954-55 döneminde rastlanılmaktadır. 1954- 55 ders y1lında 233 ilkokulda, 419 öğretmen (358 erkek-61 kadın), 16.949 öğrenci (10.836 erkek$6.113 \mathrm{k1z}$ ) mevcuduyla eğitim-öğretime devam edildi. İlkokullardan 1.362 öğrenci (1.012 erkek-350 kı) mezun oldu. Bu dönemde ortaokul sayısı 5'e yükseldi. Bu okullarda toplam 40 öğretmen (31 
erkek-9 kadın) görev yaptı. Ortaokullardaki öğrenci sayısı ise 607 (527 erkek-80 kız) idi. Bu okullardan 115 öğrenci (100 erkek-15 kız) mezun oldu. Bu dönemde şehirdeki mesleki ve teknik okullarının sayısı 4'e yükseldi. Bu okullarda 26 öğretmen (23 erkek-3 kadın), 224 öğrenciye (197 erkek-27 kız) eğitim verdi. Okullardan mezun olan öğrenci sayısı ise 27 idi. Kız öğrencilerden mezun olan yoktu. 1955 yllı 6 ve daha yukarı yaşlardaki nüfus 164.087 kişi olup (75.346 erkek- 88.741 kadın), bu nüfusun 47.849'u (35.089 erkek-12.760 kadın) okuma- yazma bilmekteydi. Bu rakam 6 ve daha yukarı yaşlardaki nüfusun \% 29.16'sına denk gelmekteydi (DİE, 1952; 1964). Okuma-yazma bilenler arasinda tespit edilen bu oran, Gümüşhane'deki en yüksek orandır.

1959-60 ders y1lında ise ilkokul sayısı 283'e ulaştı. Öğretmen sayısının 524'e (452 erkek-72 kadın) ulaştığ1 şehirdeki öğrenci sayısı 20.736 (13.768 erkek-6.968 kız) idi. Mezun olan öğrenci sayıs1 ise 1.714 (1.295 erkek-419 kı) idi. Ortaokul sayısının 6'ya yükseldiği şehirde, 52 öğretmen (42 erkek10 kadın), 1.172 öğrenciye (1.046 erkek-126 kız) eğitim verdi. Ortaokullardan 175 öğrenci (153 erkek$22 \mathrm{k1z}$ ) mezun oldu. Gümüşhane'de bir lise ise 1956'da hizmete sokuldu. 1959-60 ders y1lında lisede, 16 öğretmen (11 erkek-5 kadın), 156 öğrenciye (140 erkek-16 kız) eğitim verdi. Liseden mezun olan öğrenci sayısı ise 5’i kız olmak üzere 36 idi. Bu dönemde 4 mesleki ve teknik okulda 32 öğretmen (27 erkek-5 kadın) görev yaptı. 419 öğrenciden (380 erkek-39 kız), 133 öğrenci (122 erkek-11 kız) mezun oldu. Diğer yandan bu dönemde halk dershanelerinin sayısında ciddi bir düşüş olduğu, bir önceki dönemde 291 olan halk dershanelerinin sayısının 5'e düştüğü görülmektedir. 5 öğretmenin eğitim verdiği bu kursları toplam 55 kişi tamamlamıştı. Ayrıca şehirde 14.433 kitabının ve 15.586 okuyucusunun bulunduğu bir de halk kütüphanesi mevcuttu. 1960'da 6 ve daha yukarı yaşlardaki nüfusun sayıs1 189.114 kişi (87.641 erkek-101.473 kadın) olarak tespit edilmiştir. Nüfusun 51.812'si (37.943 erkek-13.869 kadin) okuma-yazma bilmekteydi. Okuma-yazma bilenlerin oranı ise \% 27.40 idi. Kadın nüfusunun en yüksek seviyede tespit edildiği bu dönemde, kadınların okuma-yazma oranının 13.67'de kaldığı görülmektedir (DİE, 1952; 1964).

1950-60 yılları arası dönemde; DP iktidarının eğitim politikaları, nüfus artışı ve ülkenin içinde bulunduğu istikrarlı ekonomik yapı neticesinde ilkokul binası, öğretmen ve öğrenci sayısında büyük bir artış sağlandığı görülmektedir. Bu dönemde Gümüşhane'deki ortaokul sayısı 6'ya, mesleki ve teknik okulların sayısı da 4'e yükselmiştir. Şehre bir lisenin ve bir halk kütüphanesinin kazandırılması da yine bu dönemde olmuştur. Buna rağmen okuma-yazma bilenlerin oranı \% 27'de kalmıştır. 1940'l1 yıllarda sayıları 291'i bulan halk dershanelerine ise bu dönemde çok fazla önem verilmemiştir.

Netice olarak Gümüşhane'deki eğitim faaliyetleri erken cumhuriyet dönemi, CHP dönemi ve DP döneminin kendine has şartları içerisinde gerçekleşmiştir. Dönemin zor şartları altında kısa ve uzun süreli planlamalar ile eğitim politikaları şekillendirilmiş ve her dönem kendisinden sonraki dönemin alt yapısını oluşturmuştur. Yeni gelenler, eskiden yapılanları muhafaza etmek ve yerine yenisini ilave etmek suretiyle Gümüşhane’nin eğitim ihtiyaçlarının karşılanmasına çalışmışlardır. İncelenen dönemde, 1923-1960 yıları arasında Gümüşhane'deki eğitim kurumları, öğretmen ve öğrenci sayılarını gösteren tablo aşağıdaki gibidir.

Tablo 1. 1923-1960 Yılları Arasında Gümüşhane'deki Okul, Öğretmen ve Öğrenci Sayıları

\begin{tabular}{|c|c|c|c|c|c|c|c|c|c|c|c|}
\hline \multirow{2}{*}{$\begin{array}{l}\text { Öğretim } \\
\text { Y11ı }\end{array}$} & \multirow{2}{*}{$\begin{array}{l}\text { Okul } \\
\text { Türü }\end{array}$} & \multirow{2}{*}{$\begin{array}{l}\text { Okul } \\
\text { Say1s1 }\end{array}$} & \multicolumn{3}{|c|}{ Öğretmen Sayısı } & \multicolumn{3}{|c|}{ Öğrenci Sayısı } & \multicolumn{3}{|c|}{$\begin{array}{c}\text { Diploma Alanların } \\
\text { Sayıs1 }\end{array}$} \\
\hline & & & Toplam & Erkek & Kadin & Toplam & Erkek & Kadin & Toplam & Erkek & Kadin \\
\hline \multirow{4}{*}{$1923-24$} & İlkokul & 34 & 39 & 34 & 5 & 1.152 & 1.084 & 68 & - & - & - \\
\hline & Ortaokul & - & - & - & - & - & - & - & - & - & - \\
\hline & M.Tek.Ok & - & - & - & - & - & - & - & - & - & - \\
\hline & Lise & - & - & - & - & - & - & - & - & - & - \\
\hline 1924-25 & İlkokul & 34 & 49 & - & - & 1.244 & 1.147 & 98 & - & - & - \\
\hline
\end{tabular}


Yavuz, E. (2021). Resmi istatistiklere göre Gümüşhane'de Milli Eğitim hareketleri (1923-1960), Mavi Atlas, 9(2), 148-156

\begin{tabular}{|c|c|c|c|c|c|c|c|c|c|c|c|}
\hline & Ortaokul & - & - & - & - & - & - & - & - & - & - \\
\hline & M.Tek.Ok & - & - & - & - & - & - & - & - & - & - \\
\hline & Lise & - & - & - & - & - & - & - & - & - & - \\
\hline \multirow{4}{*}{$1925-26$} & İlkokul & 55 & 68 & - & - & 1.513 & 1.393 & 120 & - & - & - \\
\hline & Ortaokul & - & - & - & - & - & - & - & - & - & - \\
\hline & M.Tek.Ok & - & - & - & - & - & - & - & - & - & - \\
\hline & Lise & - & - & - & - & - & - & - & - & - & - \\
\hline \multirow{4}{*}{$1926-27$} & İlkokul & 67 & 95 & 85 & 10 & 2.128 & 1.985 & 143 & - & - & - \\
\hline & Ortaokul & 1 & 8 & 8 & - & 29 & 29 & - & 4 & 4 & - \\
\hline & M.Tek.Ok & - & - & - & - & - & - & - & - & - & - \\
\hline & Lise & - & - & - & - & - & - & - & - & - & - \\
\hline \multirow{4}{*}{ 1934-35 } & İlkokul & 49 & 86 & 77 & 9 & 4.404 & 3.226 & 1.178 & 116 & 93 & 23 \\
\hline & Ortaokul & 2 & 17 & 16 & 1 & 146 & 137 & 9 & 21 & 19 & 2 \\
\hline & M.Tek.Ok & - & - & - & - & - & - & - & - & - & - \\
\hline & Lise & - & - & - & - & - & - & - & - & - & - \\
\hline \multirow{4}{*}{$1939-40$} & İlkokul & 132 & 186 & 174 & 12 & 8.258 & 5.987 & 2.271 & 295 & 248 & 47 \\
\hline & Ortaokul & 2 & 18 & 14 & 4 & 402 & 358 & 44 & 75 & 68 & 7 \\
\hline & M.Tek.Ok & - & - & - & - & - & - & - & - & - & - \\
\hline & Lise & - & - & - & - & - & - & - & - & - & - \\
\hline \multirow{4}{*}{$1944-45$} & İlkokul & 176 & 229 & 207 & 22 & 11.208 & 8.020 & 3.188 & 606 & 513 & 93 \\
\hline & Ortaokul & 2 & 19 & 14 & 5 & 469 & 397 & 72 & 106 & 80 & 26 \\
\hline & M.Tek.Ok & - & - & - & - & - & - & - & - & - & - \\
\hline & Lise & - & - & - & - & - & - & - & - & - & - \\
\hline \multirow{5}{*}{$1949-50$} & İlkokul & 219 & 388 & 320 & 68 & 16.917 & 10.770 & 6.147 & 1.185 & 923 & 262 \\
\hline & Ortaokul & 3 & 23 & 17 & 6 & 356 & 304 & 52 & 73 & 63 & 10 \\
\hline & M.Tek.Ok & 2 & 13 & 13 & - & 111 & 111 & - & 23 & 23 & - \\
\hline & A.K.S.Ok & 1 & 2 & - & 2 & 65 & - & 65 & - & - & - \\
\hline & Lise & - & - & - & - & - & - & - & - & - & - \\
\hline \multirow{4}{*}{ 1954-55 } & İlkokul & 233 & 419 & 358 & 61 & 16.949 & 10.836 & 6.113 & 1.362 & 1.012 & 350 \\
\hline & Ortaokul & 5 & 40 & 31 & 9 & 607 & 527 & 80 & 115 & 100 & 15 \\
\hline & M.Tek.Ok & 4 & 26 & 23 & 3 & 224 & 197 & 27 & 27 & 27 & - \\
\hline & Lise & - & - & - & - & - & - & - & - & - & - \\
\hline \multirow{4}{*}{$1959-60$} & İlkokul & 283 & 524 & 452 & 72 & 20.736 & 13.768 & 6.968 & 1.714 & 1.295 & 419 \\
\hline & Ortaokul & 6 & 52 & 42 & 10 & 1.172 & 1.046 & 126 & 175 & 153 & 22 \\
\hline & M.Tek.Ok & 4 & 32 & 27 & 5 & 419 & 380 & 39 & 133 & 122 & 11 \\
\hline & Lise & 1 & 16 & 11 & 5 & 156 & 140 & 16 & 36 & 31 & 5 \\
\hline
\end{tabular}




\section{Sonuç}

Bu çalışmada, erken Cumhuriyet döneminde başlatılan, CHP ve DP iktidarı döneminde devam edilen eğitimde yeniden yapılandırma sürecinin Gümüşhane'ye yansımaları incelenmeye çalışılmıştır. Çalışmada, 1923-1960 yılları arasında Gümüşhane'deki milli eğitim hareketleri ele alınarak, dönemin özelliği ortaya konulmaya çalışılmıştır. Bu doğrultuda incelenen dönem de şehirde faaliyet gösteren eğitim kurumları, öğretmen ve öğrenci sayıları tespit edilerek, dönemsel özelliklerin ve farklılıkların mukayese edilmesine imkân sağlanmıştır.

Cumhuriyet'in ilanından 1928 harf inkılabına kadar olan süreçte Gümüşhane'deki eğitim faaliyetlerinin, dönemin kısıtlı imkânlarına rağmen belirli bir ivme kazandığı sonucuna varılmıştır. Bu dönemde okul, öğretmen ve öğrenci sayısında kısmen de olsa bir artış kaydedildiği, özellikle 1926-27 ders yılındaki artışın önceki yıllara nazaran daha fazla olduğu tespit edilmiştir. Bu artış, Bayburt kazasının Gümüşhane sınırları içerisine dâhil edilmesiyle ilgilidir. 1928 harf inkılabından sonra yeni Türk harflerinin öğretilmesi maksadıyla açılan Millet mekteplerinin, Gümüşhane'de okuma-yazmaya yönelik önemli bir boşluğu doldurduğu sonucuna ulaşılmıştır.

1934-35 ders yılına ait istatistiki verilerden, bu dönemde şehirdeki öğrenci sayısında iki katı artış kaydedildiği, buna karşılık ilkokul binası ve öğretmen sayısında ise düşüş yaşandığı görülmüştür. Okul sayısındaki düşüşün sebebi olarak, çok eski olan okul binalarının kullanılamaz halde olması, öğretmen sayısındaki düşüş ise öğretmenlerin başka illere tayin edilmesi ya da çeşitli sebeplerden dolay1 görevlerinden ayrılmaları gösterilebilir. Bununla birlikte Gümüşhane'de okuma-yazma bilenlerin oranının nüfusa göre oldukça düşük seyrettiği sonucuna ulaşılmıştır. Ayrıca şehrin eğitim ve kültür hayatına katk1 sağlayan ve sayılar1 12'yi bulan bir diğer eğitim kurumu olan halk dershaneleri ve kurslarına bu dönemde kadın kursiyerlerin katılmadığ1 tespit edilmiştir. Bu durumun nedenleri arasında kadın öğretmenlerin bulunmaması ve şehrin sosyo-kültürel özelliğinin etkili olması gösterilebilir. Diğer yandan Gümüşhane'deki öğretmen açığının, köy eğitmenleri ile kapatılmaya çalışıldığı, artan ilkokul sayısına paralel olarak öğretmen sayısının da artırıldığı anlaşılmaktadır. Gümüşhane'de eğitimin artırılmasına yönelik çabaların devam ettiği bir dönemde 1939'da, II. Dünya Savaşı başlamıştır.

1939-50 döneminde ülke genelinde uygulamaya konulan zorunlu savaş ekonomisi eğitim faaliyetlerini de yakından etkilemiştir. Bu dönemde alınan bir takım tedbirlerle eğitim faaliyetlerinin aksatılmamasına çalışılmıştır. Millî Eğitim Şûraları, Köy Enstitüleri Kanunu ve Köy Okulları ve Enstitüleri Teşkilat Kanunu bu tedbirlerin başında gelmektedir. Diğer yandan devlet, memleketin her yerinde okul yaptırmak ve okuma yazma oranını artırmak için seferber olmuştur. Alınan tedbirler sayesinde 1944-45 eğitim-öğretim yılında, Gümüşhane'deki eğitim faaliyetlerinde her anlamda ciddi bir artışın yaşandığ1 saptanmıştır. Özellikle 1949-50 dönemi Gümüşhane'de gerek okul, gerekse öğretmen ve öğrenci sayısında en yüksek rakamlara ulaşıldığı dönemdir. II. Dünya Savaşı'nın gölgesinde şekillenen Gümüşhane'deki eğitim politikalarının ana ekseni; okuma-yazma oranının yükseltilmesi, ilkokul binası ile nitelikli öğretmen sayısının artırılması yönündedir. Bununla birlikte hizmete sokulan halk dershaneleri, ortaokullar, mesleki ve teknik okullar ve akşam kız sanat okuluyla Gümüşhane'deki eğitim hayatı canlandırılmıştır.

CHP iktidarı döneminde Gümüşhane'de gerçekleştirilen eğitim faaliyetleri DP iktidarına devredilmiştir. 1950-60 yılları arası dönemde Gümüşhane'de, CHP iktidarından devralınan eğitim mirası ve istikrarlı ekonomik yapıyla birlikte nüfus artışına paralel olarak ilkokul binası, öğretmen ve öğrenci sayısında büyük bir artış sağlandığı sonucuna ulaşılmıştır. Ortaokulların 6'ya, mesleki ve teknik okulların 4'e yükseldiği bu dönemde şehirde bir lise ve halk kütüphanesi hizmete sokulmuştur. Buna rağmen okuma- yazma bilenlerin oranı \% 27’lerde kalmıştır. Sonuç olarak incelen dönemde Gümüşhane'deki eğitim faaliyetleri her dönemin kendine has özelliği içerisinde şekillenmiş ve bir sonraki dönemin eğitim politikalarının alt yapısını oluşturmuştur. Ancak eğitim ve eğitim kurumlarının iyileştirilmesi adına gerek CHP gerekse DP iktidarı döneminde yapılan çalışmaların Türkiye 
ortalamasının çok altında kaldığı sonucuna ulaşılmıştır.

\section{Kaynakça}

Adıvar, A. A. (1991). Osmanl Türklerinde ilim. Remzi Kitabevi.

Akyüz, Y. (2011) Osmanlı döneminden cumhuriyete geçilirken eğitim-öğretim alanında yaşanan dönüşümler, Pegem Eğitim ve Ögretim Dergisi, 1(2), 9-23.

Akyüz, Y. (1994). Türk eğitim taribi (Başlangıctan 1993'e), Kültür Koleji Yayınları.

Aşgın, S. (2000). Cumburiyet döneminde Doğu Anadolu'ya yapılan kamu harcamalar (1946-1960). Atatürk Araştırma Merkezi Yayınları.

Başvekâlet İstatistik Umum Müdürlüğü. (1942). Öğgretmenler istatistiği (1934 ve 1938) (Yayın No: 185).

Cicioğlu, H. (1985). Türkiye Cumburiyeti’nde ilk ve ortä̈gretim (Taribi Gelișim). Ankara Üniversitesi DTCF Yayınları.

Devlet İstatistik Enstitüsü. (1973). Milli Eğitim'de 50 ynl (1923-1973) (Yayın No: 691).

Devlet İstatistik Enstitüsü. (1964). Türkiye istatistik ynllĭg 1952 (Yayın No: 342).

Devlet İstatistik Enstitüsü. (1964). Türkiye istatistik ynllĭgr 1964-1965 (Yayın No: 510).

Duman, Ö. (2016) Maarif yıllıklarına göre cumhuriyetin ilk çeyreğinde Gümüşhane'de eğitim (1923-1950), Mavi Atlas, 7, 55-75, https://doi.org/10.18795/ma.59468

Gümüşhane Belediyesi. (2017, Eylül). Gümüşhane taribi. Gümüşhane Rehberi.

http://www.gumushane.bel.tr/gumushane-rehberi/gumushane-tarihi/

Hesapçıŏlu, M. (2013). Türkiye'de cumhuriyet döneminde eğitim politikası ve felsefesi, M.Ü. Atatürk Eğitim Fakültesi Eğitim Bilimleri Dergisi, 29 (29), 121-138. https://dergipark.org.tr/tr/pub/maruaebd/issue/370/2124.

Kırpık, G., Ünal, U., Işık, H., Demirtaş, B., Birbudak, T. S., \& Tokdemir, M. A. (2012). Türk eğitim taribi. Otorite Yayınları.

Maarif Vekâleti. (1341). 1339-1340 ders senesi İhsaiyyat Mecmuasi, Matbaa-i Amire.

Maarif Vekâleti. (1927). 1340-1341 ders senesi İhsaiyyat Mecmuası, Matbaa-i Amire.

Maarif Vekâleti. (1928). 1925-1926 ders senesi İhsaiyyat Mecmuası, Devlet Matbaas1.

Milli Eğitim Bakanlığı. (1991). I. Maarif Şûrası 17-29 Temmuz 1939, Milli Eğitim Basımevi.

Milli Eğitim Bakanlığı. (2002). Millı eğitim sayısal veriler (2001-2002), Milli Eğitim Basımevi.

Milli Eğitim Bakanlığı. (2017, Eylül). Milli Eğitim şuralar. Talim ve Terbiye Kurulu Başkanlığı. https://ttkb.meb.gov.tr/www/milli-egitim-suralari/dosya/12 1030).

Resmi Gazete. (1928). Türk harflerinin kabul ve tatbiki hakkenda kanun, (Düstur: 3(10), 3, Say1: Yayınlar1.

Sakaoğlu, N. (2003). Osmanlidan günümüze eğitim taribi, (1. baskı). İstanbul Bilgi Üniversitesi

Yavuz, E. (2016). Erzincan'da eğitim ve eğitim kurumları (1923-1960), Turkish Studies, 11(6), 75 102, http://dx.doi.org/10.7827/TurkishStudies.9550 